\title{
Üniversite Öğrencilerinin Özel Yurt Satın Alma Davranışı: Karabük İli Örneği ${ }^{1}$
}

\author{
Nurettin Ayaz ${ }^{a^{*}}$, Sedat Başdağ ${ }^{b}$ \\ ${ }^{a}$ Karabük Üniversitesi, Safranbolu Turizm Fakültesi, Karabük. \\ ${ }^{b}$ Karabük Üniversitesi, Sosyal Bilimler Enstitüsü, Karabük.
}

\section{$\ddot{O} z$}

$B u$ araştırmada üniversite eğitimi sürecinde barınma yeri olarak özel yurtları seçen öğrencilerin özel yurt satın alma davranışlarının ortaya çıarılması amaçlanmaktadır. Bu amaç doğrultusunda Karabük ilinde özel yurtlarda kalmakta olan 445 üniversite ö̆grencisinden ŞubatHaziran 2015 döneminde anket tekniği kullanılarak veri elde edilmiştir. Anket verileri, satın alma kararı (fiziksel imkanlar, sosyokültürel imkanlar, ekonomik imkanlar) ve satın alma memnuniyeti (yemek memnuniyeti, sosyokültürel memnuniyet, yönetsel memnuniyet, çevresel memnuniyet) ilişkisi kapsamında analiz edilmiştir. Araştırma sonuçlarına göre özel yurtta kalmakta olan üniversite öğrencilerinin satın alma kararına yönelik düşünceleri ile satın alma sonrası memnuniyetleri arasında pozitif yönlü ve orta düzeyde anlamlı bir ilişki bulunmuştur. Öğrencilerin özel yurt satın alma kararlarında yurdun sahip olduğu fiziksel imkanlar ilk sirada yer alırken, satın alma sonrası memnuniyetlerinde yönetsel memnuniyet beklentileri öne çımıştır.

Anahtar Kelimeler: Barımma, özel yurt, satın alma motivasyonu, satın alma memnuniyeti, Karabük.

\section{University Students' Buying Behaviour of Private Dormitories: The Case of Karabük}

\begin{abstract}
This study aims to reveal the private dormitory purchasing behaviors of the students that choose these dormitories as their place of accommodation. In accordance with this aim, data was obtained from 445 university students staying at private dormitories in the city of Karabük by using survey technique between February-June 2015. Within the scope of survey data, purchasing decision (physical opportunities, socio-cultural opportunities, economic opportunities) and purchasing satisfaction (food satisfaction, socio-cultural satisfaction, environmental satisfaction) relation were analyzed. The findings suggest medium level positive relationship between the university students' thoughts about purchasing decision and satisfaction after the purchase. During private boarding house purchasing decisions of the students, physical abilities rank the first whereas their administrative satisfaction expectations in their satisfaction after the purchase became prominent.
\end{abstract}

Keywords: Harboring, private dormitory, purchasing satisfaction, purchasing motivation, Karabük.

\footnotetext{
${ }^{1}$ Bu araştırma, Karabük Üniversitesi Sosyal Bilimler Enstitüsü İşletme Anabilim Dalı "Tüketici Satın Alma Karar Süreci: Üniversite Öğrencilerinin Özel Yurt Seçimleri ve Memnuniyetleri" başlıklı tez çalışmasından üretilmiştir.
}

* Yazışma adresi. Email: nurettinayaz@karabuk.edu.tr 


\section{GíRiş}

Bireyin kişisel ve sosyal hayatını doğudan etkileyebilen unsurlardan bir tanesini de barınma oluşturur. Barınma; güvenlik ve sağlık gereksinimlerini karşılayan bir olgu olmasının yanı sıra kişisel, sosyal ve psikolojik gelişimi de etkiler ve barınma şartları nesnel olarak sosyal hayatın niteliğini ve niceliği ortaya çıkarır (Arlı, 2013; Güldiken ve Özekicioğlu, 2004).

Barınma, bulunduğu şehirden yükseköğrenim almak için farklı bir şehre giden öğrencinin karşılaştığı öncelikli sorunlardan birisidir. Üniversite öğrencilerinin büyük bölümü öğrenim için ailesinin yanından uzaklaşmasıyla ortaya çıkan, çoğalan üniversite sayısı ve öğrenci kapasitesiyle gündemdeki popülerliğini koruyan ciddi bir sorundur. Bu sorun öğrenci yurtlarının talep kapasitesi ihtiyacını karşılayamaması nedeniyle önemini artırmaktadır (Ersoy ve Arpac1, 2003).

Üniversite öğrencileri barınma sorunu kapsamında alternatif çözüm arayışlarına yönelmekte ve başarılı bir eğitim kariyeri için huzurlu ve güvenli bir barınma ortamı oluşturma arayışına yönelmektedirler. Öğrenciler, barınma ihtiyaçları kapsaminda kamu ve özel sektöre ait yurtlarda, özel pansiyonlarda, apart otellerde, kiralık evlerde, ailesinin ya da akrabalarının yanında ve öğrenci evlerinde kalabilmektedirler. Barınma biçimlerinin seçilmesinde, öğrencinin kendisinin ve ailesinin sosyo-ekonomik durumu, üniversite öğrenimi için bulunduğu şehirdeki barınma amaçlı konutların kapasitesi gibi faktörler etkili olabilmektedir (Filiz ve Çemrek, 2007). Barınma, üniversite öğrencilerinin başarısını doğrudan etkileyen önemli bir faktördür. Bu nedenle öğrencilerin üniversite yaşamı boyunca etkileşim içinde oldukları önemli ortamlar olarak barınma yerlerinin öğrencilerin kişisel ve sosyal gelişim için koşullarının bilinmesi ve sürekli geliştirilmesini gerekliliği vurgulanmaktadır (Koçbeker, 2007; Arlı, 2013).

Üniversite öğrencileri, barınma ihtiyaçlarını gidermek için farklı çözüm yolları üretebilmekte ve satın alma davranışları sergilemektedirler. Öğrenciler satın alma davranışlarında birçok faktörün etkisi altında kalmaktadır. Bu karmaşık süreçte öğrenciler ihtiyaçlarını en iyi biçimde karşılayacak, kendilerini tatmin edecek en iyi barınma imkânı sağlayabilecek yerleri bulma arayışı içerisindedirler (Türkay, 2011). Üniversite öğrencilerinin barınma yeri seçim tercihlerinde birçok değişken etkilidir. Bu nedenle barınma yeri seçiminde öğrencilerin davranışlarında farklılıklar görülebilmektedir. Bazı öğrenciler sahip olduğu değerlerin etkisiyle kanaatkâr bir yaşam sürdürmeyi seçerken (Özdemir ve Yaman, 2007). Ekonomik imkânları daha yüksek olan öğrenciler özel pansiyonları barınma mekânı olarak seçmektedirler.

$\mathrm{Bu}$ araştırma, Karabük ilinde özel yurt hizmeti sunan işletmelere katkı sağlamak düşüncesiyle kurgulanmıştır. Araştırmada özel yurt hizmeti satın alan üniversite öğrencilerinin satın alma güdüleri ile satın alma memnuniyetleri arasındaki ilişkinin öğrenilmesi amaçlanmaktadır. Bu doğrultuda araştırma problemi "özel yurt hizmeti satın alan üniversite öğrencilerinin satın alma motivasyonları ile satın alma memnuniyetleri arasında anlamlı bir ilişkinin bulunup bulunmadığını tespit etmek" olarak belirlenmiştir. 


\section{LITERATÜR}

Pazarlama biliminde nihai ürünü satın alan kişiler tüketici kapsamında değerlendirilmektedir. Gerçek veya tüzel kişiler şeklinde ortaya çıkabilen tüketicilerin bir ürünün satın alırken kendi değerleri ve prensipleri doğrultusunda hareket sergiledikleri öngörülmektedir (Çakmak ve Gümüşbuğa, 2013). Tüketicilerin bir ürünü satın alma kararı verirken çoğunlukla "ne satın alayım, ne kadar satın alayım, nereden satın alayım, ne zaman satın alayım ve nasıl satın alayım" sorularına verdikleri cevaplar doğrultusunda hareket ettikleri öne çıkartılmaktadır (Koç, 2013: 399). Bununla birlikte hızlı teknolojik gelişmeler, ekonomilerin büyümesi, toplumsal yapıların değişmesi, tüketicilerin bilgi seviyelerinin yükselmesi ve artan rekabet nedeniyle tüketicilerin beklentilerinin ve tüketim sonrası davranışlarının incelenmesi ve işletmelerin bu yönde pazarlama stratejileri oluşturmaları beklenmektedir (Şahbaz ve Şapcilar, 2014).

Pazarlamacılarının tüketicilerin satın alma kararanını nasıl verdikleri anlaması önemlidir. Satın alma karar sürecinde kararın kim tarafından verildiği ve satın alma adımların bilinmesi, rekabet avantajı oluşturmak açısından kaçınılmaz bir gerekliliktir (Kotler, 2000). Tüketiciler, kendisine en fazla yarar sağlayabilecek sınırsız sayıdaki mal ve hizmet bileşimlerini seçmekte özgür olmakla birlikte, en fazla ihtiyaç duyduğu malı ilk önce; daha az ihtiyaç duyduğu malı ise en son satın alarak faydasını maksimum etme çabası içindedirler (Tarı ve Pehlivanoğlu, 2007). Çünkü tüketiciler gerek birey olarak gerekse sosyal açılardan (çevre, aile, referans grupları, rol ve statü vb.) birçok faktörün etkisi altında kalmaktadır. Bu faktörler, tüketicinin satın alma davranış kararlarını çeşitli şekillerde etkilemektedir (Ünlüönen ve Tayfun, 2003).

Tüketici satın alma davranışlarını etkileyen dört temel faktör üzerinde durulmaktadır. Bunlar; sosyal faktörler, kültürel faktörler, psikolojik faktörler ve demografik faktörlerdir. Sosyal faktörlerde; aile, danışma grupları, rol ve statü, kültürel faktörler arasında; kültür, alt kültür, sosyal sınıf, psikolojik faktörler içerisinde; güdülenme, algılama, öğrenme, inanç ve tutum yer almaktadır. Demografik faktörler ise yaş, cinsiyet, gelir, eğitim ve meslek gibi bireysel karakteristik nitelikleri içermektedir (Örücü ve Tavşanc1, 2001).

Tablo 1. Satın Alma Davranışını Etkileyen Faktörler

\begin{tabular}{lllll}
\hline Sosyal & Kültürel & Psikolojik & Demografik & \\
Faktörler & Faktörler & Faktörler & Faktörler & \\
\cline { 1 - 5 } Aile & Kültür & Güdüleme & Yaş & \multirow{2}{*}{ Tüketici } \\
Danışma & Alt kültür & Algılama & Cinsiyet & \\
Grupları & Sosyal Sınıf & Öğrenme & Gelir & \\
Rol ve Statü & & İnanç ve & Eğitim & \\
& & Tutum & Meslek & \\
& & &
\end{tabular}

Kaynak: Bekâr ve Gövce, 2015: 947 den uyarlanmıştır. 
Tüketici mevcut ihtiyaçlarını giderebilmek için gereksinim duyduğu mal ve hizmetleri satın alma kararında birçok süreçten geçebilmektedirler. Tüketicilerin satın alma davranışları üründen ürüne çeşitlilik gösterebilmektedir. Gıda ürünleri; belirli alışkanlıklar sonucunda daha az çaba harcanarak, pahalı ürünler; fiyat, ödeme koşulları, nitelikleri, markaların ayrıntıları gibi özellikler kapsamında alışılmış, karmaşık, uyumsuzluğu azaltan ve farklılık araştırıcı satın alınabilmektedir (Kotler, 2000: Yükselen, 2006; Taşyürek, 2010; Türkay, 2011; Akkaya, 2012; Koçoğlu, 2014;).

Yükseköğretim eğitim sürecinde öğrencilerinin büyük bir kısmı ailelerinden ayrı olarak başka bir kentte öğrenimlerini sürdürmek durumundadırlar. Bu durumun sonucunda öğrenciler bir takım sorunlarla yüzleşmek ve mücadele etmek zorundadırlar. Ayrıca, yeni bir çevrede tanımadığı bireylerle ilişki kurma ve geliştirme, barınma, beslenme, ekonomik zorlukları aşma, sosyal ve kültürel gereksinimlerini karşılama, toplumsal baskılar ve gençliğin kendine özgü genel sorunlar da öne çıkan sorunlar arasında yer almaktır (Şahin vd., 2009).

Üniversite eğitim sürecinde üniversite öğrencilerinin, karşılaştıkları problemler; barınma, gelecek kaygısı, iş bulma, ekonomik hayat, üniversite yaşamı, sosyal ve boş zamanı değerlendirme, sağlık, öğretim ve öğretim yöntemleri, insanlarla ilişki kurma, aile, karşı cins ilişkileri, din ve ahlak ile ilgili problemlerle ilişkilendirilmektedir (Özgüven, 1992). Bu süreçte başarılı olmak isteyen öğrencilerin üniversiteden çeşitli beklentileri ise mesleki rehberlik, akademik ve psikolojik danışmalık, daha iyi kütüphane hizmeti, maddi yardım veya nereden maddi yardım alınabileceğine ilişkin bilgi sağlanması, ders programlarının uygun hale getirilmesi, derslerin kalitesinin ve seçmeli ders sayısının artırılması, sınıf geçme sisteminin değiştirilmesi, yetersiz olan öğretim elemanlarının değiştirilmesi ve yurt veya barınma konusunda bilgi sağlanması şeklinde ifade edilmektedir (Şahin vd., 2009).

Barınma problemi, özellikle ailesinden uzakta üniversite öğrencileri için yaşam ve sağlık sorunudur. Öğrenciye barınma yeri sağlamak ne kadar önemliyse, o yerin temiz olması ve öğrencinin kendisini o yerde rahat hissetmesi de o kadar önem arz etmektedir (Yavuzer vd., 2005: 89). Ailesiyle beraber ikamet ettiği ilde üniversite okuyacak olan öğrenciler ailesinin yanında konaklarken, şehir dışında üniversite kazanan öğrenciler ise barınma sorununu tek başına veya birkaç arkadaşı ile evde kalma ya da özel veya devlet yurtlarında barınarak çözmektedirler (Arlı, 2013).

Sağlık ve beslenme faktörleri ile oldukça ilişkili bir faktör olan barınma, artan üniversite ve öğrenci sayısına karşılık öğrenci yurt kapasitelerinin yetersiz kalması, nedeniyle halen ciddî boyutlarda çözümlenmesi gereken bir sorundur (Kara, 2009: 3). Barınma kapsamında öğrencilerin en çok gündeme taşıdıkları sorunlar; kahvaltıdaki gıdalar, yemek çeşitleri ve lezzeti, kantinin ihtiyacı, odalarda buzdolabı bulunmaması, etüt odalarının öğrenciler için yeterli olmaması, çalışma odasındaki malzemelerin ihtiyaçları karşılayamaması ve ders çalışmak için öğrenci sayısına göre eğitim ortamının bulunmaması olarak sıralanmaktadır (Gökyer, 2012).

Üniversite öğrencilerinin barınma sorununa ilişkin önceki araştırmalarda; barınma şekillerinin ders başarılarına etkisi (Çelik ve Arpacık,1991), öğrencilerinin 
sağlık, barınma ve ulaşım gibi sorunlarının öğrenilmesi (Esatoğlu ve Köse, 2002), devlet yurtlarında, özel yurtlarda ve öğrenci evlerinde kalan öğrencilerin sosyal ve kültürel özellikleri ile neden farklı barınma mekanlarında kalmayı tercih ettikleri (Güldiken ve Özekicioğlu, 2004), üniversite öğrencilerinin başarısında çevresel faktörlerin etkisi (Şeker vd, 2004), sınıf ortamı ve barınma sorunlarından kaynaklanan olumsuzlukların öğrenci başarısına etkisi (Kaya vd., 2005), öğrencilerinin barınma durumu ve sorunları (Filiz ve Çemrek, 2007) üniversite öğrencilerinin rekreasyon alışkanlıkları ve yurtların bu konuda öğrencilere sağladığı imkanların yeterliliği (Tekin vd., 2007), özel öğrenci yurtlarında kalan öğrencilerin yurt yönetiminden kaynaklanan sorunlar (Gökyer, 2012), yurtta veya evde kalmanın olumlu ve olumsuz etkileri (Arl,, 2013), öğrencilerin yurttan memnuniyetleri (Turan ve Ünsel, 2014) üniversite öğrencilerine barınma hizmeti sunan iki özel yurt işletmesinden barınma hizmeti satın alan öğrencilerin, hizmet kalitesi ve hizmet beklentileri (Ok ve Girgin, 2015) araştırılmıştır. Literatürde üniversite öğrencilerinin özel yurtlardan konaklama hizmeti satın alma kararı ve memnuniyet ilişkisine yönelik herhangi bir çalışmaya rastlanmamıştır.

\section{YÖNTEM}

$\mathrm{Bu}$ araştırma özel yurtlardan konaklama hizmeti satın alan üniversite öğrencilerinin motivasyonları ve memnuniyetleri arasındaki ilişkiyi ortaya koymaya yönelik bir betimsel araştırma olup tarama modeli (geçmişte ya da halen var olan bir durumu olduğu şekliyle betimleme) üzerine kurulu olup, araştırmada şu hipotezlerinin test edilmesi öngörülmüştür:

$H_{1}$ : Özel yurt hizmeti satın alan üniversite öğrencilerinin satın alma motivasyonları ile satın alma memnuniyetleri arasında anlamlı bir ilişki vardır.

$\mathrm{H}_{1-1}$ Özel yurt hizmeti satın alan üniversite öğrencilerinin sosyokültürel imkân motivasyonu ile yemek memnuniyetleri arasında anlamlı bir ilişki vardır.

$\mathrm{H}_{1-2}$ : Özel yurt hizmeti satın alan üniversite öğrencilerinin sosyal imkân motivasyonu ile hizmet memnuniyetleri arasında anlamlı bir ilişki vardır.

$H_{1-3:}$ Özel yurt hizmeti satın alan üniversite öğrencilerinin sosyokültürel imkân motivasyonu ile yönetsel memnuniyetleri arasında anlamlı bir ilişki vardır.

$H_{1-4:}$ Özel yurt hizmeti satın alan üniversite öğrencilerinin sosyokültürel imkân motivasyonu ile çevresel memnuniyetleri arasında anlamlı bir ilişki vardır.

$\mathrm{H}_{1-5}$ : Özel yurt hizmeti satın alan üniversite öğrencilerinin fiziksel imkân motivasyonu ile yemek memnuniyetleri arasında anlamlı bir ilişki vardır.

$\mathrm{H}_{1-6}$ : Özel yurt hizmeti satın alan üniversite öğrencilerinin fiziksel imkân motivasyonu ile hizmet memnuniyetleri arasında anlamlı bir ilişki vardır.

$\mathrm{H}_{1-7}$ : Özel yurt hizmeti satın alan üniversite öğrencilerinin fiziksel imkân motivasyonu ile yönetsel memnuniyetleri arasında anlamlı bir ilişki vardır. 
$\mathrm{H}_{1-8}$ : Özel yurt hizmeti satın alan üniversite öğrencilerinin fiziksel imkân motivasyonu ile çevresel memnuniyetleri arasında anlamlı bir ilişki vardır.

$\mathrm{H}_{1-9}$ Özel yurt hizmeti satın alan üniversite öğrencilerinin ekonomik imkân motivasyonu ile yemek memnuniyetleri arasında anlamlı bir ilişki vardır.

$\mathrm{H}_{1-10}$ : Özel yurt hizmeti satın alan üniversite öğrencilerinin ekonomik imkân motivasyonu ile hizmet memnuniyetleri arasında anlamlı bir ilişki vardır.

$\mathrm{H}_{1-11}$ Özel yurt hizmeti satın alan üniversite öğrencilerinin ekonomik imkân motivasyonu ile yönetsel memnuniyetleri arasında anlamlı bir ilişki vardır.

$\mathrm{H}_{1-12:}$ Özel yurt hizmeti satın alan üniversite öğrencilerinin ekonomik imkân motivasyonu ile çevresel memnuniyetleri arasında anlamlı bir ilişki vardır.

Araştırma hipotezlerinde satın alma motivasyonunda etkili olan fiziksel imkânlar, sosyal imkânlar ve ekonomik imkânlar bağımsız değişkenler; memnuniyet kapsaminda test edilen yemek memnuniyeti, hizmet memnuniyeti, yönetsel memnuniyet ve çevresel memnuniyet bağımlı değişkenler olarak ele alınmıştır.

Araştırmada evreni 2014-2015 öğretim y1lında Karabük İl Milli Eğitim Müdürlüğü Özel Öğretim Hizmetleri'ne kayıtlı 27 özel yurtta kalmakta olan 3.248 öğrenci olarak kabul edilmiştir. Araştırma alanının genişliği, zaman ve maliyet unsurları çerçevesinde bu araştırmada örnekleme başvurulmuştur. Örneklem büyüklüğü için \%95 güven aralığı ve $Z$ değeri 1,96 olarak kabul edilmiş ve örneklem büyüklüğü 344 katılımcı olarak belirlenmiştir.

Özel yurtlarda konaklama hizmeti satın alan üniversite öğrencilerinin motivasyonları ile memnuniyetlerine yönelik verilerin toplanmasında anket tekniğinden faydalanılmıştır. Araştırmanın uygulama bölümüne yönelik anket ölçeği geliştirme sürecinde, Gökyer (2012), Arlı (2013), Filiz ve Çemrek (2007), Güldiken ve Özekicioğlu (2004), araştırmalarından faydalanılmıştır. Araştırmaya yönelik sorular akademisyen görüşü kapsamında araştırmacılar tarafından geliştirilmiştir. Hazırlanan anket; araştırmacı tarafından kolayda örneklem yöntemi ve yüz yüze görüşme tekniği kapsamında özel yurtlarda konaklayan üniversite öğrencilerine Ocak ve Haziran 2015 dönemi içerisinde uygulanmıştır. Toplam 500 anket dağıtılmış, bu anketlerden 480 anketten geri dönüş sağlanmış, (geri dönüş oranı \%96) ve araştırma kullanılabilecek 445 anket üzerinden gerçekleştirilmiştir.

Veri toplamak için kullanılan anket üç kısımdan oluşmaktadır. Anketin ilk kısmında; katılımcıların demografik (cinsiyet, yaş, okul türü, öğrenim şekli, sınıf, aylık gelir) ve diğer (özel yurtta kalış süresi, kalınan kaçıncı özel yurt sayısı) özellikleri sınıflama ölçeği; ikinci ve üçüncü kısımlarda yurt satın alma motivasyonları ve satın alma memnuniyetlerini belirlenmesine yönelik aralıklı ölçek kapsamında geliştirilen sorular yer almıştır. Aralıklı ölçek olarak 5'li Likert Ölçeği kullanılmıştır. Öğrencilerin özel yurt satın alma kararlarının ortaya çıkarılmasında 5'li Likert tipi (1=Hiç Katılmıyorum; 2=Az Katılıyorum; 3=Orta Düzeyde Katılıyorum; 4=Çok Katılıyorum; 5=Tamamen Katılıyorum) ölçek, yurt memnuniyetinin ortaya konulmasında 5'li Likert 
tipi (1=Hiç Memnun Değilim; 2=Az Memnunum; 3=Orta Düzeyde Memnunum; 4=Çok Memnunum; 5=Tamamen Memnunum) ölçek kullanılmıştır.

Araştırma kapsamında, anket yoluyla toplanan veriler, bilgisayar ortamına aktarılarak veri tabanı oluşturulmuştur. Araştırma anketinden elde edilen verilerin araştırma sorularını test etmeye uygunluğu kapsamında güvenirlik ve açımlayıcı faktör analizi gerçekleştirilmiştir. Verilerin, faktör analizine uygunluğu kapsamında gerçekleştirilen Kasier-Meyer-Olkin (KMO) katsayısı ve Barlett Sphericity (Bartlett) testi sonuçları kullanılmıştır. Faktör analizi sonuçları ve her bir faktöre ilişkin güvenirlik katsayıları (Cronbach's Alpha) Tablo 2 ve Tablo 3 'te verilmiştir. Büyüköztürk (2007), verilerin faktör analizi için uygunluğunda KMO'nun 0,60'dan yüksek ve Bartlett Sphericity testinin anlamlı çıkması halinde yapılabileceğini belirtmektedir. Ayrıca, tek faktörlü ölçeklerde açılanan varyansın \%30 ya da daha yüksek ve psikolojik bir test için hesaplanan güvenirlik katsayısının 0,70 ve üzeri olması durumunda açıklayıcı olabileceğini vurgulamaktadır.

Özel yurt satın alma motivasyonlarına yönelik Tablo 3 verileri incelendiğinde faktörlerin; "sosyokültürel imkan motivasyonu", "fiziksel imkan motivasyonu" ve "ekonomik imkan motivasyonu" sırasında ve toplam varyans açıklama oranlarının \%73,8 olmak üzere üç grupta toplandığı görülmektedir.

Tablo 2. Özel Yurt Satın Alma Motivasyonlarına Yönelik Faktör Analizi

\begin{tabular}{|c|c|c|c|c|c|}
\hline Faktör & $\bar{x}$ & $\sigma$ & $\begin{array}{l}\text { Faktör } \\
\text { Yükü }\end{array}$ & $\begin{array}{l}\text { Cronbach } \\
\text { Alpha }\end{array}$ & $\begin{array}{c}\text { Varyans } \\
\text { Açılklama } \\
(\%)\end{array}$ \\
\hline Sosyokültürel İmkan Motivasyonu & 2,55 & 1,14 & & & 31,632 \\
\hline $\begin{array}{l}\text { Sosyokültürel etkinlikler (folklor, } \\
\text { satranç vb) }\end{array}$ & 2,21 & 1,35 & 0,807 & 0,768 & \\
\hline Revir bulunması & 2,52 & 1,49 & 0,797 & 0,757 & \\
\hline Spor olanakları & 2,57 & 1,44 & 0,791 & 0,759 & \\
\hline Kantin hizmetinin bulunması & 2,87 & 1,47 & 0,697 & 0,777 & \\
\hline Fiziksel İmkan Motivasyonu & 3,26 & 1,09 & & & 21,552 \\
\hline Yurt binasının fiziki görünümü & 3,24 & 1,19 & 0,923 & 0,800 & \\
\hline Yurt binasının iç dekorasyonu & 3,28 & 1,17 & 0,894 & 0,787 & \\
\hline Ekonomik İmkan Motivasyonu & 3,03 & 1,31 & & & 20,631 \\
\hline Ödeme kolaylığı sunulması & 3,11 & 1,40 & 0,884 & 0,779 & \\
\hline Fiyat uygunluğu & 2,93 & 1,50 & 0,870 & 0,779 & \\
\hline $\begin{array}{l}\text { Toplam Cronbach Alpha/Varyans } \\
\text { Açıklama (\%) }\end{array}$ & & & & 0,799 & 73,815 \\
\hline
\end{tabular}

K-M-O Measure of Sampling Adequacy: 0,75

Bartlett's Test of Sphericity (Chi-Square / df / Sig: 1252,436/28/0,000

Özel yurt satın alma memnuniyetlerine yönelik Tablo 4 verileri kapsamında faktörlerin; "yemek memnuniyeti", "hizmet memnuniyeti" ve "yönetsel memnuniyet" ve "çevresel memnuniyet" öncelik sırasında ve toplam varyans açılama oranlarının \%70,6 olmak üzere dört grupta toplandığı görülmektedir. 
Tablo 3. Özel Yurt Satın Alma Memnuniyetlerine Yönelik Faktör Analizi

\begin{tabular}{|c|c|c|c|c|c|}
\hline Faktör & $\bar{x}$ & $\sigma$ & $\begin{array}{l}\text { Faktör } \\
\text { Yükü }\end{array}$ & $\begin{array}{l}\text { Cronbach } \\
\text { Alpha }\end{array}$ & $\begin{array}{c}\text { Varyans } \\
\text { Açıklama } \\
(\%)\end{array}$ \\
\hline Yemek Memnuniyeti & 2,92 & 1,09 & & & 21,848 \\
\hline Yemeklerinin sıcaklığg & 3,04 & 1,26 & 0,806 & 0,912 & \\
\hline Yemeklerinin besin değeri & 2,90 & 1,19 & 0,790 & 0,909 & \\
\hline Yemeklerinin lezzeti & 2,94 & 1,28 & 0,776 & 0,909 & \\
\hline Yemeklerinin kalitesi & 2,93 & 1,32 & 0,760 & 0,907 & \\
\hline Yemek menüleri & 2,82 & 1,32 & 0,666 & 0,909 & \\
\hline Hizmet Memnuniyeti & 2,52 & 1,08 & & & 20,077 \\
\hline Kantinde satılan ürünlerin fiyatları & 2,45 & 1,32 & 0,819 & 0,912 & \\
\hline Kantin hizmeti saatleri & 2,71 & 1,40 & 0,798 & 0,913 & \\
\hline Kantinde satılan ürünlerin çeşitliği & 2,64 & 1,38 & 0,794 & 0,912 & \\
\hline Sosyokültürel olanaklara erişim & 2,41 & 1,39 & 0,640 & 0,913 & \\
\hline Spor olanaklarına erişim & 2,42 & 1,41 & 0,606 & 0,915 & \\
\hline Yönetsel Memnuniyet & 3,13 & 1,07 & & & 17,848 \\
\hline Çalışanlarının öğrencilere davranışı & 3,20 & 1,21 & 0,796 & 0,911 & \\
\hline Çalışanlarının öğrencilere ilgi ve alakası & 3,04 & 1,29 & 0,776 & 0,911 & \\
\hline Ortak kullanım alanlarının temizliği, & 3,11 & 1,28 & 0,750 & 0,910 & \\
\hline Odamın temizliği & 3,21 & 1,29 & 0,723 & 0,913 & \\
\hline Çevresel Memnuniyet & 2,99 & 1,13 & & & 10,827 \\
\hline Yurt çevresindeki alış veriş imkanları & 3,18 & 1,34 & 0,817 & 0,918 & \\
\hline Yurt çevresindeki yerel halkla ilişkiler & 2,81 & 1,26 & 0,742 & 0,915 & \\
\hline $\begin{array}{l}\text { Toplam Cronbach Alpha / Varyans } \\
\text { Açıklama (\%) }\end{array}$ & & & & 0,917 & 70,600 \\
\hline
\end{tabular}

K-M-O Measure of Sampling Adequacy: 0,891

Bartlett's Test of Sphericity (Chi-Square / df / Sig: 4318,081/ 120 / 0,000

\section{BULGULAR}

Tablo 4'te araştırmaya dâhil üniversite öğrencilerinin demografik (cinsiyet, yaş, okul türü, öğrenim şekli, sınıf, aylık gelir) ve diğer (özel yurtta kalış süresi, kalınan özel yurt sayısı) özelliklerine yönelik frekans ve yüzde dağılımlarına ait bilgiler verilmiştir.

Tablo 4'e göre araştırmaya dahil olan üniversite öğrencilerinin \%40,2'si erkek, $\% 59,8^{\prime} i$ ise kadınlardan oluşmaktadır. Anketi cevaplayan üniversite öğrencilerinin yaş dağılımları; \%55,3'ü 17-21 yaş, \%44,7'ü 22 yaş ve üzeri gruplarında toplanmıştır. Katılımcıların okul türü gözlendiğinde \%16,6'sının meslek yüksekokulu, \%7,6'sının yüksekokul, \%75,7'sinin fakülteden oluşuştur. Öğrencilerin sinıf dağılımları; 1 . sinıf $(\% 39,3)$, 2. sınıf, $(\% 33,0)$, 3. sinıf $(\% 15,7)$ ve 4 . sinıf $(\% 11,9)$ olarak tespit edilmiştir. Katılımcıların aylık gelirleri incelendiğinde \%31,2'sinin 500 ve altı, \%50,3'ünün 501 ile 1000 TL arası, \%18,4'ının 1001 TL ve üzeri gelire sahip olduğu görülmektedir. Öğrencilerin özel yurtta kaldığı süre değişkeninde; \%41,3'ü 1 yıl ve altı, \%29,7'si 2 yıl, \%13,5'i 3 yıl ve \%15,5'i 4 yıl ve üzeri olmak üzere özel yurtlarda konakladıkları tespit 
edilmiştir. Katılımcıların kaldığı özel yurt sayısı dağılımında \%63,6'sının ilk özel yurdu olduğu görülürken, \%26,5'nun ikinci özel yurdu ve \%9,9'nun üçüncü kez özel yurtta kalındığ 1 görülmektedir.

$\mathrm{Bu}$ sonuçlar kapsamında üniversite öğrencilerinin demografik özellikler açısından cinsiyet yönünden kadın, yaş aralığında 17-21 yaş grubu, okul türü yönünden fakülte, öğrenim şekli açısından 1. öğretim, sınıf bakımından 1. sınıf, aylık gelir bakımından 501 ile 1000 TL aralığı özel yurtta kalış süresi olarak 1 yıl ve altı, kalınan özel yurt sayısı açısından ise birinci özel yurdum değişkeni öne çıkmıştır.

Tablo 4. Demografik ve Diğer Özelliklerine İlişkin Bilgiler ( $\mathrm{n}=445)$

\begin{tabular}{|c|l|c|c|c|l|c|c|}
\hline & & & & & \\
\hline
\end{tabular}

Tablo 5'te özel yurtlardan konaklama hizmeti satın alan üniversite öğrencilerinin sosyokültürel imkan motivasyonuna ilişkin bulgular yer almaktadır. Sosyokültürel imkan motivasyonuna yönelik satın alma kararında öne çıan en önemli yargılar; yurtta kantin hizmetinin bulunması $(\bar{x}=2,87)$, yurttaki spor olanakları $(\bar{x}=2,57)$, yurtta revirin bulunması $(\bar{x}=2,52)$ ve yurttaki sosyokültürel etkinlikler $(\bar{x}=2,21)$ olmuştur. Bununla birlikte sosyokültürel imkan motivasyonlarına yönelik bütün yargıların 2,5 ortalamaya yakın ve altında kalması öğrencilerin yurt hizmeti satın almada sosyokültürel imkan motivasyonlarına çok önem vermediği şeklinde yorumlanabilir. 
Tablo 5. Sosyokültürel İmkan Motivasyonuna İlişkin Bulgular (n=445)

\begin{tabular}{|c|c|c|c|c|c|c|c|c|}
\hline \multicolumn{2}{|l|}{ İfadeler } & 岗 & 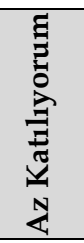 & 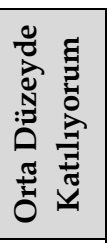 & ن & 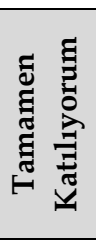 & $\bar{x}$ & $\sigma$ \\
\hline \multirow{2}{*}{$\begin{array}{l}\text { Yurttaki sosyokültürel etkinlikler } \\
\text { (folklor, satranç vb.) }\end{array}$} & $\mathrm{f}$ & 199 & 79 & 80 & 44 & 43 & \multirow[b]{2}{*}{2,21} & \multirow[b]{2}{*}{1,35} \\
\hline & $\%$ & 44,7 & 17,8 & 18,0 & 9,9 & 9,7 & & \\
\hline \multirow{2}{*}{ Yurtta revir bulunması } & $\mathrm{f}$ & 178 & 49 & 92 & 58 & 68 & \multirow[b]{2}{*}{2,52} & \multirow[b]{2}{*}{1,49} \\
\hline & $\%$ & 40,0 & 11,0 & 20,7 & 13,0 & 15,3 & & \\
\hline \multirow{2}{*}{ Yurttaki spor olanakları } & $\mathrm{f}$ & 156 & 69 & 91 & 68 & 61 & \multirow[b]{2}{*}{2,57} & \multirow[b]{2}{*}{1,44} \\
\hline & $\%$ & 35,1 & 15,5 & 20,4 & 15,3 & 13,7 & & \\
\hline \multirow{2}{*}{ Yurtta kantin hizmetinin bulunması } & $\mathrm{f}$ & 121 & 57 & 101 & 82 & 84 & \multirow[b]{2}{*}{2,87} & \multirow[b]{2}{*}{1,47} \\
\hline & $\%$ & 27,2 & 12,8 & 22,7 & 18,4 & 18,9 & & \\
\hline
\end{tabular}

Tablo 6'da özel yurtlardan konaklama hizmeti satın alan üniversite öğrencilerinin fiziksel imkan motivasyonuna ilişkin bulgular yer almaktadır. Tablo 6 kapsamında öğrencilerin fiziksel imkan motivasyonlarında yurt binasının iç dekorasyonu $(\bar{x}=3,28)$ ve yurt binasının fiziki görünümünün $(\bar{x}=3,24)$ özel yurt hizmeti satın almasında etkili olduğu belirlenmiştir. Bu sonuçlar kapsamında öğrencilerin yurt hizmeti satın alma karar sürecinde en etkili unsurun fiziksel imkan motivasyonlarına yönelik olduğu şeklinde söylenebilir.

Tablo 6: Fiziksel İmkan Motivasyonuna İlişkin Bulgular ( $\mathrm{n}=445)$

\begin{tabular}{|c|c|c|c|c|c|c|c|c|}
\hline \multicolumn{2}{|l|}{ İfadeler } & 诖 & 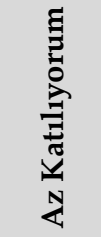 & 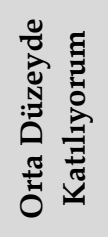 & 论 & 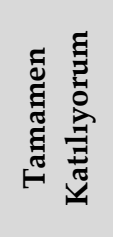 & $\bar{x}$ & $\sigma$ \\
\hline \multirow{2}{*}{ Yurt binasının fiziki görünümü } & $\mathrm{f}$ & 49 & 54 & 151 & 118 & 73 & \multirow{2}{*}{3,24} & \multirow{2}{*}{1,19} \\
\hline & $\%$ & 11,0 & 12,1 & 33,9 & 26,5 & 16,4 & & \\
\hline \multirow{2}{*}{ Yurt binasının iç dekorasyonu } & $\mathrm{f}$ & 39 & 68 & 140 & 122 & 76 & \multirow{2}{*}{3,28} & \multirow{2}{*}{1,17} \\
\hline & $\%$ & 8,8 & 15,3 & 31,5 & 27,4 & 17,1 & & \\
\hline
\end{tabular}

Tablo 7'de özel yurtlardan konaklama hizmeti satın alan üniversite öğrencilerinin ekonomik imkan motivasyonuna ilişkin bulgular yer almaktadır. Öğrencileri; ödeme kolaylığı sunulması ( $\bar{x}=3,11)$ ilk sırada yer almaktadır. Bu durumu fiyat uygunluğu $(\bar{x}=2,93)$ takip etmektedir. Ekonomik imkan motivasyonu boyutunda ödeme kolaylığı ve fiyat uygunluğunun 3 ortalamanın üzerinde olması özel yurt tercihinde fiziksel imkan motivasyonlarından sonra ikinci öncelikli olduğu söylenebilir. 
Tablo 7: Ekonomik İmkan Motivasyonuna İlişkin Bulgular ( $\mathrm{n}=445)$

\begin{tabular}{|c|c|c|c|c|c|c|c|c|}
\hline \multicolumn{2}{|l|}{ İfadeler } & 诖 & 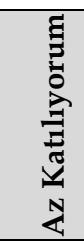 & 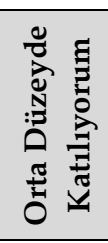 & ن & 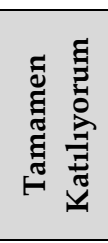 & $\bar{x}$ & $\sigma$ \\
\hline \multirow{2}{*}{ Ödeme kolaylığı sunulması } & $\mathrm{f}$ & 80 & 69 & 115 & 78 & 103 & \multirow{2}{*}{3,11} & \multirow{2}{*}{1,40} \\
\hline & $\%$ & 18,0 & 15,5 & 25,8 & 17,5 & 23,1 & & \\
\hline \multirow{2}{*}{ Fiyat uygunluğu } & $\mathrm{f}$ & 114 & 73 & 85 & 73 & 100 & \multirow{2}{*}{2,93} & \multirow{2}{*}{1,50} \\
\hline & $\%$ & 25,6 & 16,4 & 19,1 & 16,4 & 22,5 & & \\
\hline
\end{tabular}

Tablo 8'de özel yurtlardan konaklama hizmeti satın alan üniversite öğrencilerinin yemek memnuniyetlerine ilişkin bulgular yer almaktadır. Tablo 8'de görüldüğü üzere özel yurt hizmeti satın alan üniversite öğrencilerinin satın alma sonrası memnuniyetlerinde; yurt yemeklerinin sicaklığı $(\bar{x}=3,04)$, yurt yemeklerinin lezzeti $(\bar{x}=2,94)$, yurt yemeklerinin kalitesi $(\bar{x}=2,93)$, yurt yemeklerinin besin değeri $(\bar{x}=2,901)$ ve yemek menüleri $(\bar{x}=2,82)$ önem derecesine göre siralanmıştır. Bu sonuçlar kapsamında satın alma sonrası memnuniyette yurt yemeklerinin önemli olduğu ve yemek memnuniyetini dikkate alan özel yurt işletmelerinin gelecekteki satışlarında başarılı olacağı şeklinde yorumlanabilir.

Tablo 8. Yemek Memnuniyetine İlişkin Bulgular ( $\mathrm{n}=445)$

\begin{tabular}{|c|c|c|c|c|c|c|c|c|}
\hline \multicolumn{2}{|l|}{ İfadeler } & פ & 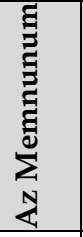 & 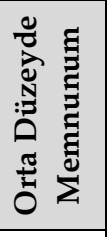 & 啳 & 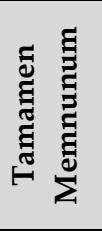 & $\bar{x}$ & $\sigma$ \\
\hline \multirow{2}{*}{ Yurt yemeklerinin sıcaklığı } & f & 71 & 72 & 135 & 104 & 63 & \multirow{2}{*}{3,041} & \multirow{2}{*}{1,26} \\
\hline & $\%$ & 16,0 & 16,2 & 30,3 & 23,4 & 14,2 & & \\
\hline \multirow{2}{*}{ Yurt yemeklerinin besin değeri } & $\mathrm{f}$ & 73 & 83 & 152 & 93 & 44 & \multirow{2}{*}{2,901} & \multirow{2}{*}{1,19} \\
\hline & $\%$ & 16,4 & 18,7 & 34,2 & 20,9 & 9,9 & & \\
\hline \multirow{2}{*}{ Yurt yemeklerinin lezzeti } & $\mathrm{f}$ & 86 & 71 & 126 & 110 & 52 & \multirow{2}{*}{2,942} & \multirow{2}{*}{1,28} \\
\hline & $\%$ & 19,3 & 16,0 & 28,3 & 24,7 & 11,7 & & \\
\hline \multirow{2}{*}{ Yurt yemeklerinin kalitesi } & $\mathrm{f}$ & 93 & 70 & 115 & 107 & 60 & \multirow{2}{*}{2,933} & \multirow{2}{*}{1,32} \\
\hline & $\%$ & 20,9 & 15,7 & 25,8 & 24,0 & 13,5 & & \\
\hline \multirow{2}{*}{ Yemek menüleri } & $\mathrm{f}$ & 97 & 83 & 126 & 81 & 58 & \multirow{2}{*}{2,823} & \multirow{2}{*}{1,32} \\
\hline & $\%$ & 21,8 & 18,7 & 28,3 & 18,2 & 13,0 & & \\
\hline
\end{tabular}

Tablo 9'da özel yurtlardan konaklama hizmeti satın alan üniversite öğrencilerinin hizmet memnuniyetlerine ilişkin bulgular yer almaktadır. Özel yurtlardan konaklama hizmeti satın alan öğrencilerin hizmet memnuniyetine yönelik öne çıkardıkları en önemli yargı; yurttaki kantin hizmeti saatleri $(\bar{x}=2,71)$ olmuştur. Bu yargıyı yurt kantininde satılan ürünlerin çeşitliği $(\bar{x}=2,64)$ takip etmiştir. 
Tablo 9: Hizmet Memnuniyetine İlişkin Bulgular ( $n=445)$

\begin{tabular}{|c|c|c|c|c|c|c|c|c|}
\hline \multicolumn{2}{|l|}{ İfadeler } & 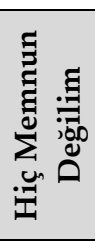 & 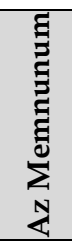 & 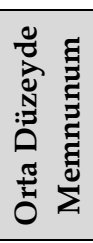 & 光 & ఏ్ & $\bar{x}$ & $\sigma$ \\
\hline \multirow{2}{*}{$\begin{array}{l}\text { Yurt kantininde satılan ürünlerin } \\
\text { fiyatları }\end{array}$} & $\mathrm{f}$ & 150 & 86 & 102 & 69 & 38 & \multirow{2}{*}{2,459} & \multirow{2}{*}{1,32} \\
\hline & $\%$ & 33,7 & 19,3 & 22,9 & 15,5 & 8,5 & & \\
\hline \multirow{2}{*}{ Yurttaki kantin hizmeti saatleri } & $\mathrm{f}$ & 127 & 75 & 101 & 82 & 60 & \multirow{2}{*}{2,710} & \multirow{2}{*}{1,40} \\
\hline & $\%$ & 28,5 & 16,9 & 22,7 & 18,4 & 13,5 & & \\
\hline \multirow{2}{*}{$\begin{array}{l}\text { Yurt kantininde satılan ürünlerin } \\
\text { çeşitliği }\end{array}$} & $\mathrm{f}$ & 135 & 71 & 112 & 73 & 54 & \multirow{2}{*}{2,641} & \multirow{2}{*}{1,38} \\
\hline & $\%$ & 30,3 & 16,0 & 25,2 & 16,4 & 12,1 & & \\
\hline \multirow{2}{*}{ Sosyokültürel olanaklar } & $\mathrm{f}$ & 175 & 70 & 92 & 61 & 47 & \multirow{2}{*}{2,413} & \multirow{2}{*}{1,39} \\
\hline & $\%$ & 39,3 & 15,7 & 20,7 & 13,7 & 10,6 & & \\
\hline \multirow{2}{*}{ Spor imkânları } & $\mathrm{f}$ & 180 & 61 & 88 & 72 & 44 & \multirow{2}{*}{2,420} & \multirow{2}{*}{1,41} \\
\hline & $\%$ & 40,4 & 13,7 & 19,8 & 16,2 & 9,9 & & \\
\hline
\end{tabular}

Tablo 10'da özel yurtlardan konaklama hizmeti satın alan üniversite öğrencilerinin yönetsel memnuniyetine ilişkin bulgular yer almaktadır. Öğrencilerin yönetsel memnuniyet boyutunda öne çıkan düşünceleri “odamın temizliği" $(\bar{x}=3,21)$, "yurt çalışanlarının öğrencilere davranışı” $(\bar{x}=3,20)$, “ortak kullanım alanlarının temizliği" $(\bar{x}=3,11)$ ve "yurt çalışanlarının öğrencilere ilgi ve alakası" $(\bar{x}=3,04)$ şeklinde sıralanmaktadır. Öğrencilerin satın alma sonrası memnuniyetlerinde (yemek memnuniyeti, hizmet memnuniyeti, yönetsel memnuniyet, çevresel memnuniyet) en etkili memnuniyet boyutunu yönetsel memnuniyet oluşturmuştur.

Tablo 10: Yönetsel Memnuniyete İlişkin Bulgular ( $n=445)$

\begin{tabular}{|c|c|c|c|c|c|c|c|c|}
\hline \multicolumn{2}{|l|}{ İfadeler } & 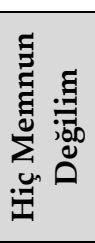 & 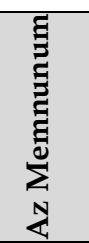 & 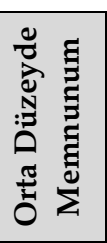 & 品 & 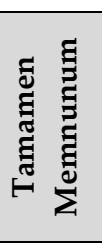 & $\bar{x}$ & $\sigma$ \\
\hline \multirow{2}{*}{$\begin{array}{l}\text { Yurt çalışanlarının öğrencilere } \\
\text { davranışı }\end{array}$} & $\mathrm{f}$ & 56 & 62 & 135 & 124 & 68 & \multirow{2}{*}{3,20} & \multirow{2}{*}{1,21} \\
\hline & $\%$ & 12,6 & 13,9 & 30,3 & 27,9 & 15,3 & & \\
\hline \multirow{2}{*}{$\begin{array}{l}\text { Yurt çalışanlarının öğrencilere ilgi ve } \\
\text { alakası }\end{array}$} & $\mathrm{f}$ & 74 & 74 & 133 & 88 & 76 & \multirow{2}{*}{3,04} & \multirow{2}{*}{1,29} \\
\hline & $\%$ & 16,6 & 16,6 & 29,9 & 19,8 & 17,1 & & \\
\hline \multirow{2}{*}{ Ortak kullanım alanlarının temizliği } & $\mathrm{f}$ & 74 & 59 & 127 & 116 & 69 & \multirow{2}{*}{3,11} & \multirow{2}{*}{1,28} \\
\hline & $\%$ & 16,6 & 13,3 & 28,5 & 26,1 & 15,5 & & \\
\hline \multirow{2}{*}{ Odamın temizliği } & $\mathrm{f}$ & 64 & 60 & 118 & 121 & 82 & \multirow{2}{*}{3,21} & \multirow{2}{*}{1,29} \\
\hline & $\%$ & 14,4 & 13,5 & 26,5 & 27,2 & 18,4 & & \\
\hline
\end{tabular}

Tablo 11'de özel yurtlardan konaklama hizmeti satın alan üniversite öğrencilerinin çevresel memnuniyetlerine ilişkin bulgular yer almaktadır. Yurt hizmeti satın alan öğrencilerin çevresel memnuniyetlerinde öne çıkan yargı; yurt çevresindeki 
alış veriş imkanları $(\bar{x}=3,18)$ olarak belirlenmiştir. Bu yargıyı yurt çevresindeki yerel halkla olan ilişkiler $(\bar{x}=2,81)$ izlemektedir. Çevresel memnuniyet ortalaması $(\bar{x}=2,99)$ olarak belirlenmiştir. Bu bulgular kapsamında özel yurt hizmeti satın alma kararında çevresel memnuniyetin önemli olduğu söylenebilir. Bu kapsamda özel yurt işletmelerinin diş çevresi ile geliştireceği ilişkiler önem arz etmektedir.

Tablo 11: Çevresel Memnuniyete İlişkin Bulgular ( $n=445)$

\begin{tabular}{|c|c|c|c|c|c|c|c|c|}
\hline \multicolumn{2}{|l|}{ Iffadeler } & 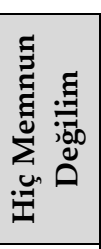 & 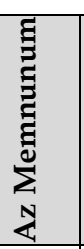 & 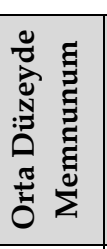 & 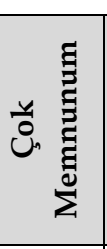 & 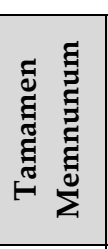 & $\bar{x}$ & $\sigma$ \\
\hline \multirow{2}{*}{ Yurt çevresindeki alış veriş imkanları } & $\mathrm{f}$ & 73 & 60 & 115 & 110 & 87 & \multirow{2}{*}{3,18} & \multirow{2}{*}{1,34} \\
\hline & $\%$ & 16,4 & 13,5 & 25,8 & 24,7 & 19,6 & & \\
\hline \multirow{2}{*}{$\begin{array}{l}\text { Yurt çevresindeki yerel halkla olan } \\
\text { ilişkiler }\end{array}$} & $\mathrm{f}$ & 94 & 77 & 145 & 79 & 50 & \multirow{2}{*}{2,81} & \multirow{2}{*}{1,26} \\
\hline & $\%$ & 21,1 & 17,3 & 32,6 & 17,8 & 11,2 & & \\
\hline
\end{tabular}

Özel yurt hizmeti satın alan öğrencilerin satın alma motivasyonları ile satın alma memnuniyetleri arasındaki ilişkilere yönelik korelasyon analizi yapılmıştır. Elde edilen sonuçlar Tablo 12' de sunulmuştur.

Korelasyon katsayısı " $\mathrm{r}$ " (-1) ile (+1) arasında bir değer alabilir. Katsayının 1,00 olması, iki değişken arasında ilişkinin pozitif yönde olduğunu yani bir değişkenin artması diğer değişkeninde artması veya bir değişkenin değerinin azalması diğerinin de azalması anlamına gelmektedir. Katsayının -1,00 olması, iki değişken arasında ki ilişkinin negatif yönde gerçekleştiğini yani bir değişkene ilişkin verilerin artması durumunda diğer verinin azalmasına veya bir değişkene ilişkin verilerin azalması durumunda diğerinin artması olarak değerlendirilir. 0,00 olması ise iki değişken arasında herhangi bir ilişkinin olmadığını gösterir (Büyüköztürk, 2007: 32). Değerlendirilen değişkenler arasında ilişki düzeyi, " $r$ " değerinin 0,00-0,29 arasında olması durumunda düşük bir ilişki olduğunu, 0,30-0,69 arasında olması durumunda orta düzeyde bir ilişkinin, 0,70 ve üzeri olması durumunda ise yüksek düzeyde ilişkinin varlığından söz edilebilir (Ural ve Kılıç, 2006).

Tablo 12'deki bulgulara göre özel yurtlardan konaklama hizmeti satın alan üniversite öğrencilerinin satın alma motivasyonları (fiziksel imkan, sosyokültürel imkan, ekonomik imkan) ile satın alma memnuniyetleri (yemek memnuniyeti, hizmet memnuniyeti, yönetsel memnuniyet, çevresel memnuniyet) arasında 0,001 anlamlılık düzeyinde bir ilişki bulunmuştur. Tüm faktörler arasındaki " $r$ " değeri anlamlı çıkmıştır $(p<0,001)$. Özel yurtlardan konaklama hizmeti satın alan üniversite öğrencilerinin konaklama hizmeti satın alma motivasyonları ile memnuniyetleri arasında anlamlı bir ilişki olduğu $(\mathrm{r}=0,622)$ tespit edilmiştir. Bu kapsamda özel yurtlardan konaklama hizmeti satın alma motivasyonu yüksek olan öğrencilerinin, satın alma memnuniyetinin artacağı sonucuna ulaşılabilir. 
Tablo 12. Özel Yurt Hizmeti Satın Alma Kararında Motivasyon ve Memnuniyet Arasındaki İlişkiye Ait Korelasyon Analizi

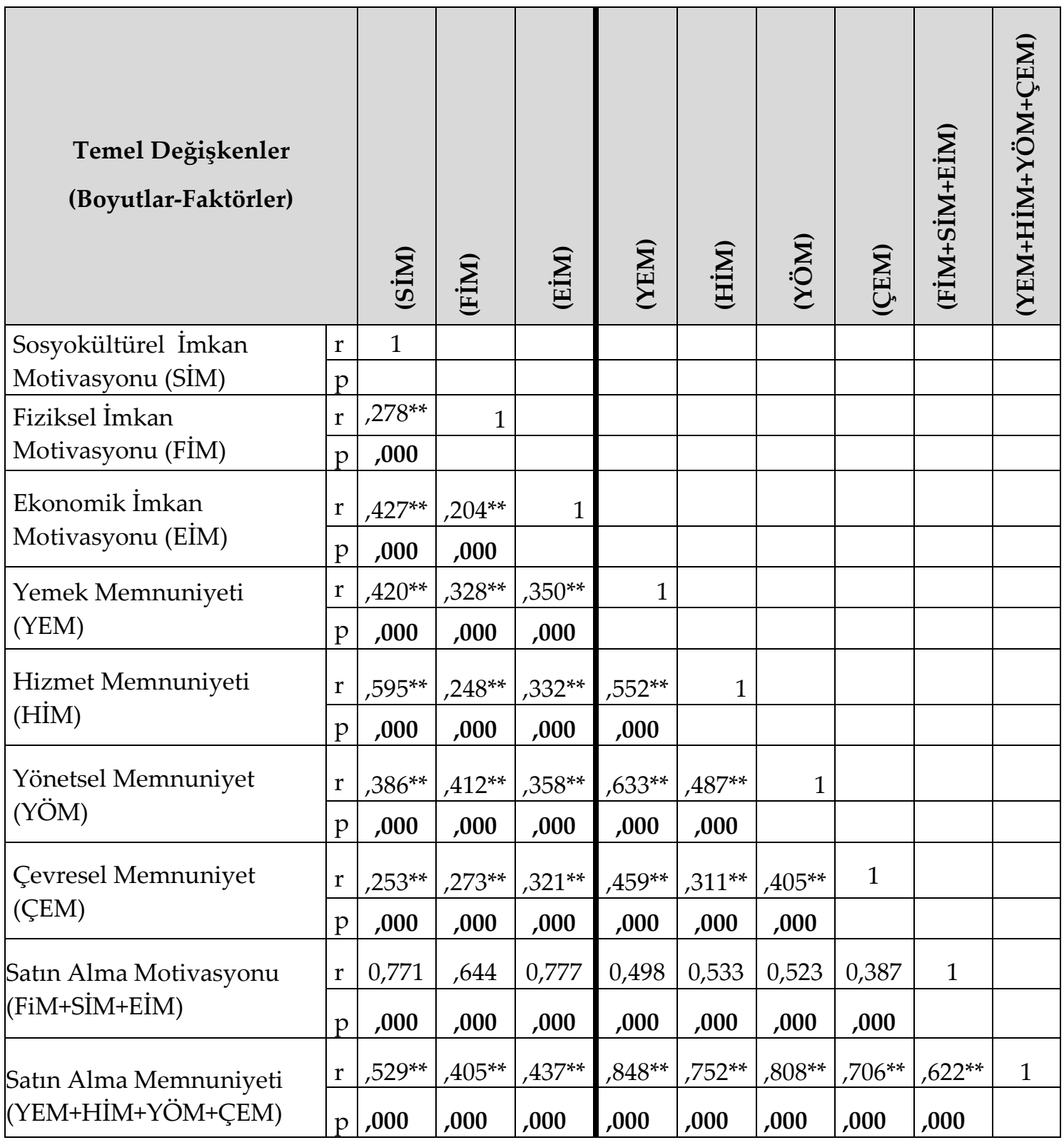

${ }^{* *}(\mathrm{p}<0,001)$

Yukarıdaki korelasyon sonuçları kapsamında özel yurt hizmeti satın alan üniversite öğrencilerinin satın alma güdüleri ve memnuiyetlerine yönelik " $r$ " ve " $p$ " değerleri kapsamında Tablo 13'te araştırma hipotezlerinin "kabul edilme" ve "kabul edilmeme" durumları şu şekilde belirlenmiştir. 
Tablo 13: Araştırma Hipotezlerinin Sonuçları

\begin{tabular}{|c|c|}
\hline Hipotezler & Sonuç \\
\hline $\begin{array}{l}\text { H1: Özel yurt hizmeti satın alan üniversite öğrencilerinin satın alma } \\
\text { motivasyonları ile satın alma memnuniyetleri arasında anlamlı bir ilişki } \\
\text { vardır. }\end{array}$ & $\begin{array}{l}\text { KABUL } \\
\text { EDİLMIŞTİR }\end{array}$ \\
\hline $\begin{array}{l}\text { H1-1: Özel yurt hizmeti satın alan üniversite öğrencilerinin sosyokültürel } \\
\text { imkan motivasyonu ile yemek memnuniyetleri arasında anlamlı bir ilişki } \\
\text { vardır. }\end{array}$ & $\begin{array}{l}\text { KABUL } \\
\text { EDİLMİSTTIR }\end{array}$ \\
\hline $\begin{array}{l}\text { H1-2: Özel yurt hizmeti satın alan üniversite öğrencilerinin sosyokültürel } \\
\text { imkan motivasyonu ile hizmet memnuniyetleri arasında anlamlı bir ilişki } \\
\text { vardır. }\end{array}$ & $\begin{array}{l}\text { KABUL } \\
\text { EDILILIŞTİR }\end{array}$ \\
\hline $\begin{array}{l}\text { H1-3: Özel yurt hizmeti satın alan üniversite öğrencilerinin sosyokültürel } \\
\text { imkan motivasyonu ile yönetsel memnuniyetleri arasında anlamlı bir ilişki } \\
\text { vardır. }\end{array}$ & $\begin{array}{l}\text { KABUL } \\
\text { EDİLMIŞTIR }\end{array}$ \\
\hline $\begin{array}{l}\text { H1-4: Özel yurt hizmeti satın alan üniversite öğrencilerinin sosyokültürel } \\
\text { imkan motivasyonu ile çevresel memnuniyetleri arasında anlamlı bir ilişki } \\
\text { vardır. }\end{array}$ & $\begin{array}{l}\text { KABUL } \\
\text { EDİMMIŞTIR }\end{array}$ \\
\hline $\begin{array}{l}\text { H1-5: Özel yurt hizmeti satın alan üniversite öğrencilerinin fiziksel imkan } \\
\text { motivasyonu ile yemek memnuniyetleri arasında anlamlı bir ilişki vardır. }\end{array}$ & $\begin{array}{l}\text { KABUL } \\
\text { EDİLMIŞTIR }\end{array}$ \\
\hline $\begin{array}{l}\text { H1-6: Özel yurt hizmeti satın alan üniversite öğrencilerinin fiziksel imkan } \\
\text { motivasyonu ile hizmet memnuniyetleri arasında anlamlı bir ilişki vardır. }\end{array}$ & $\begin{array}{l}\text { KABUL } \\
\text { EDİLMIŞTIR }\end{array}$ \\
\hline $\begin{array}{l}\text { H1-7: Özel yurt hizmeti satın alan üniversite öğrencilerinin fiziksel imkan } \\
\text { motivasyonu ile yönetsel memnuniyetleri arasında anlamlı bir ilişki vardır. }\end{array}$ & $\begin{array}{l}\text { KABUL } \\
\text { EDİLMISTTIR }\end{array}$ \\
\hline $\begin{array}{l}\text { H1-8: Özel yurt hizmeti satın alan üniversite öğrencilerinin fiziksel imkan } \\
\text { motivasyonu ile çevresel memnuniyetleri arasında anlamlı bir ilişki vardır. }\end{array}$ & $\begin{array}{l}\text { KABUL } \\
\text { EDİLMISTTIR }\end{array}$ \\
\hline $\begin{array}{l}\text { H1-9: Özel yurt hizmeti satın alan üniversite öğrencilerinin ekonomik } \\
\text { imkan motivasyonu ile yemek memnuniyetleri arasında anlamlı bir ilişki } \\
\text { vardır. }\end{array}$ & $\begin{array}{l}\text { KABUL } \\
\text { EDİLMIŞTIR }\end{array}$ \\
\hline $\begin{array}{l}\mathrm{H}_{1-10} \text { : Özel yurt hizmeti satın alan üniversite öğrencilerinin ekonomik } \\
\text { imkan motivasyonu ile hizmet memnuniyetleri arasında anlamlı bir ilişki } \\
\text { vardır. }\end{array}$ & $\begin{array}{l}\text { KABUL } \\
\text { EDİLMIŞTİR }\end{array}$ \\
\hline $\begin{array}{l}\text { H1-11: Özel yurt hizmeti satın alan üniversite öğrencilerinin ekonomik } \\
\text { imkan motivasyonu ile yönetsel memnuniyetleri arasında anlamlı bir ilişki } \\
\text { vardır. }\end{array}$ & $\begin{array}{l}\text { KABUL } \\
\text { EDILMIŞTİR }\end{array}$ \\
\hline $\begin{array}{l}\text { H1-12: Özel yurt hizmeti satın alan üniversite öğrencilerinin ekonomik } \\
\text { imkan motivasyonu ile çevresel memnuniyetleri arasında anlamlı bir ilişki } \\
\text { vardır. }\end{array}$ & $\begin{array}{l}\text { KABUL } \\
\text { EDILILIŞTİR }\end{array}$ \\
\hline
\end{tabular}




\section{SONUÇ VE TARTIŞMA}

Yükseköğrenim sürecinde barınma mekanı, öğrencinin eğitim başarısını şekillendirebilen önemli bir öğedir. Barınma, öğrencinin birçok komplike ihtiyacını (güvenlik, beslenme, ders çalışma, sosyalleşme vb.) sunan bir unsurdur. Bu nedenle barınma yeri ve içerisinde sunulan hizmetlerin sunuluş şekli oldukça önem arz eder. Bu nedenle barınma ile ilgili paydaşların (öğrenciler, işletme yöneticileri, işgörenler, üniversiteler, yerel yönetimler) düşüncelerinin akademik çalışmalara taşınması ve öğrencilerin barınma sorununa yönelik araştırmaların sayıca artması gerekmektedir.

$\mathrm{Bu}$ çalışmada üniversite öğrencilerin özel yurtlarda barınma hizmeti satın alma güdüleri ve memnuniyetleri arasındaki ilişkiyi test edilmiştir. İhtiyaçlarını gidermek için mal veya hizmet talep eden tüketicilerin ürün satın alma davranışı ekonomik, sosyal ve psikolojik güdünün etkisinde ortaya çıabilmektedir. Bu nedenle pazarlama sürecinde tüketiciyi satın almaya yönlendiren güdülerin ortaya çıkarılması ve satın alma süreçlerine etkisinin test edilmesi önem arz etmektedir.

Özel yurtlardan konaklama hizmeti satın alan üniversite öğrencilerinin satın alma motivasyonlarının öncelik sırası; fiziksel imkanlar motivasyonu, ekonomik imkanlar motivasyonu ve sosyokültürel imkanlar motivasyonu olarak tespit edilmiştir. Bu sonuçlar kapsamında Karabük ilindeki üniversite öğrencilerinin özel yurtlardan konaklama hizmeti satın alma kararlarında en önemli motivasyon kaynağının fiziksel imkanlar, en düşük motivasyon kaynağı ise sosyokültürel imkanların oluşturduğu söylemek mümkündür.

Özel yurtlardan konaklama hizmeti satın alan üniversite öğrencilerinin satın alma memnuniyetlerinde öncelik sıralaması; yönetsel memnuniyet, çevresel memnuniyet, yemek memnuniyeti ve hizmet memnuniyeti olup, bu bulgular kapsamında özel yurtlardan konaklama hizmeti satın alan üniversite öğrencilerinin en yüksek memnuniyetini; yönetsel memnuniyet, en düşük memnuniyetlerin ise hizmet memnuniyeti boyutunda ortaya çıktığını söylemek mümkündür.

Özel yurtlardan konaklama hizmeti satın alan üniversite öğrencilerinin sosyokültürel imkan motivasyonu ile yemek memnuniyeti $(r=0,420)$, hizmet memnuniyeti $(r=0,595)$, yönetsel memnuniyet $(r=0,386)$, çevresel memnuniyeti $(r=0,253)$ arasında anlamlı bir ilişkiye rastlanmıştır. Bu sonuçlar kapsamında sosyokültürel imkan motivasyonunun öğrencilerin memnuniyetleriyle ilişkili olduğu $(r=0,529)$ tespit edilmiştir. Bu kapsamda özel yurtlar, öğrencilerinin satın alma memnuniyetlerini artırmak isterlerse, satın alma karar sürecinde sosyokültürel imkanları onların zihnine yerleştirebilecek çalışmalara (satış geliştirme) yönelmeleri gerekmektedir.

Özel yurtlardan konaklama hizmeti satın alan üniversite öğrencilerinin fiziksel imkan motivasyonu ile yemek memnuniyeti $(\mathrm{r}=0,328)$, hizmet memnuniyeti $(\mathrm{r}=0,248)$, yönetsel memnuniyet $(\mathrm{r}=0,412)$, çevresel memnuniyeti $(\mathrm{r}=0,273)$ arasında anlamlı bir ilişki tespit edilmiştir. Bu sonuçlar göstermektedir ki fiziksel imkan motivasyonu ile öğrencilerin memnuniyetleri ilişkilidir $(\mathrm{r}=0,405)$. Bu kapsamda özel yurtlar, öğrencilerinin satın alma memnuniyetlerini artırmak isterlerse, satın alma karar 
sürecinde fiziksel imkanlarını standartların gerektirdiği düzeyde tutmalarının önemini ortaya koymaktadır.

Özel yurtlardan konaklama hizmeti satın alan üniversite öğrencilerinin ekonomik imkan motivasyonu ile yemek memnuniyeti $(\mathrm{r}=0,350)$, hizmet memnuniyeti $(\mathrm{r}=0,332)$, yönetsel memnuniyet $(\mathrm{r}=0,358)$, çevresel memnuniyeti $(\mathrm{r}=0,321)$ arasında anlamlı bir ilişki tespit edilmiştir. Bu sonuçlar göstermektedir ki ekonomik imkan motivasyonu ile öğrencilerin memnuniyetlerini $(\mathrm{r}=0,437)$ artırmaktadır. Bu kapsamda özel yurtlar, öğrencilerin ekonomik imkanlarını göz önünde bulunduracak satış teknikleri geliştirmeleri gerektiği söylenebilir.

Araştırma sonuçları kapsamında; özel yurtlardan konaklama hizmeti satın alan üniversite öğrencilerinin satın alma davranışlarına yönelik geliştirilen öneriler şu şekilde sıralanabilir:

- Özel yurt işletmecileri, konaklama hizmeti satın alma aşamasındaki potansiyel öğrencilerin motivasyonlarını saptamalı ve bu doğrultuda beklentilere yönelik ön hazırlıklara yönelmelidirler. Bu süreçte fiziksel imkan, ekonomik imkan ve sosyokültürel imkan motivasyonlarına öncelik sırasına göre uyarıcı çalışmalar yapmalıdırlar.

- Özel yurt işletmecileri, konaklama hizmeti satın alma kararı aşamasındaki öğrencilere nazik davranmalıdır. Unutmamalıdırlar ki konaklama hizmetinden memnun olacak bir öğrenci, barındığı yurdu diğer arkadaşlarına ağıdan ağıza reklam yoluyla tavsiye edecektir. Bu nedenle özel yurtlar taşıma kapasitelerine uygun gelişim ve büyüme politikaları sergilemelidirler.

- Özel yurt işletmecileri, sunacakları hizmetlerde yemek, hizmet, yönetsel ve çevresel memnuniyet öncelik sırasında hizmetlerinin kalitelerini yükseltmeli ve hizmetlerinin satışına ve sunumuna yönelik standartlar oluşturmalıdırlar.

- Özel yurt işletmeleri, sahip bulunduğu imkânlar konusunda tutundurma (reklam, kişisel satış, satış geliştirme, halkla ilişkiler) çalışmalarına sıkça başvurmalı ve öğrencileri rakip işletmelerden farklılıkları konusunda bilgilendirmelidirler.

$\mathrm{Bu}$ araştırmada, özel yurtlardan konaklama hizmeti satın alan üniversite öğrencilerinin satın alma güdüleri ve memnuniyetlerine yönelik tüketici davranışları kapsamında kavramsal bir yapı oluşturulmuştur. Araştırmanın Türkiye'deki özel yurt işletmelerine yol gösterici olması beklenmektedir. Bununla birlikte gelecekte yapılacak benzer araştırmalarda, araştırmacıların şu hususları dikkate alınması yararlı olabilecektir:

- Özel yurtlardan konaklama hizmeti satın alan üniversite öğrencilerinin sosyokültürel imkan, fiziksel imkan ve ekonomik imkan güdüleri incelenmiştir. Benzer çalışmalarda üniversite öğrencilerinin başka güdülerine (ulaşım, güvenlik vb.) üzerine odaklanmak farklı bakış açıları oluşturabilir. 
- Özel yurtlardan konaklama hizmeti satın alan üniversite öğrencilerinin memnuniyetleri (yemek, hizmet, yönetsel, çevresel) incelenmiştir. Gelecekteki çalışmalarda öğrencilerin başka memnuniyetlerine (boş zamanı değerlendirme, verimli ders çalışma) üzerine çalışılması farklı öngörüler oluşturabilir.

- Özel yurtlardan konaklama hizmeti satın alan üniversite öğrencilerinin motivasyon ve memnuniyet ölçekleri, başka barınma mekanlarında (devlet yurdu, misafirhane) kalan öğrencilere uygulanarak yeni bir bakış açıları geliştirilebilir.

Bu araştırma sonuçları göstermiştir ki özel yurtlardan konaklama hizmeti satın alan üniversite öğrencilerinin satın alma motivasyonları, satın alma memnuniyetlerini orta düzeyde artırmaktadır. Bu sonuç, özel yurt işletmelerine gelecekte yapacakları satış planlamalarında öğrencilerin motivasyonlarından yararlanılabileceğini göstermektedir. Bununla birlikte, özel yurt işletmeleri yöneticilerinin belirli periyotlarda öğrencilerin beklenti ve memnuniyetlerini ölçme konusunda konuda bilgi düzeylerinin artırılması faydalı olacaktır. Bu süreçte başta özel yurt işletmesinin bulunduğu yerel yönetimler ve Kredi Yurtlar Kurumu Genel Müdürlüğü olmak üzere ortak çalışmalarla öğrencilerin tüketici davranışı konusunda araştırmalar yapılabilir.

\section{KAYNAKÇA}

Arlı, E. (2013). Barınma Yerinin Üniversite Öğrencilerinin Kişisel ve Sosyal Gelişim ve Akademik Başarı Üzerindeki Etkilerinin Odak Grup Görüşmesi İle İncelenmesi. Yükseköğretim ve Bilim Dergisi 3(2), 173-178.

Bekar, A., Gövce, A. M. (2015). Tüketicilerin Gıda Satın Alma Davranışları İle Yaşam Tarzı İlişkisi. Uluslararası Sosyal Araştırmalar Dergisi, 8(36), 946-958.

Büyüköztürk, Ş. (2007). Sosyal Bilimler İçin Veri Analizi El Kitabı: İstatistik, Araştırma Deseni, SPPP Uygulamaları ve Yorum. Ankara: Pagem A Yayıncılık.

Çakmak, A. Ç. ve Gümüşbuğa, F. (2013). Yerel Ürünlerin Pazarlara Açılmasında Alternatif Bir Ticaret Modeli Olan İnsaflı Ticaretin Yerel Üreticiler Tarafından Kullanılabilirliğinin Araştırılması: Karabük İlinde Bir Uygulama. 18. Pazarlama Kongresi Bildiri Kitabı (s.212), Kars.

Ersoy, A. F. ve Arpacı, F. (2003). Üniversite Öğrencilerinin Konut Koşullarının ve Konutta Yaşamayı Tercih Etme Nedenlerinin İncelenmesi. Milli Eğitim Dergisi, Bahar(158), Web: http://dhgm.meb.gov.tr/yayimlar/dergiler/Milli_Egitim_Dergisi/158/ersoy.htm adresinden 22 Eylül 2014' de alınmıştır.

Esatoğlu, E. ve Köse A. (2002). Ankara Üniversitesi Dikimevi Sağllk Hizmetleri Meslek Yüksekokulu Öğrencilerinin Kendi Sağlık Sorunlarıyla İlgili Düşünceleri. Ankara Üniversitesi Dikimevi Sağlık Hizmetleri Meslek Yüksekokulu Yıllığı, 3(1), 7-12.

Filiz, Z. ve Çermek, F. (2007). Üniversite Öğrencilerinin Barınma Sorunlarının Uygunluk Analizi ile İncelenmesi. Eskişehir Osmangazi Üniversitesi Sosyal Bilimler Dergisi, 8(2), 207-224.

Gökyer, N. (2012). Özel Öğrenci Yurtlarında Kalan Öğrencilerin Yurt Yönetiminden Kaynaklanan Sorunlara İlişkin Görüşleri (Elazığ İli Örneği). International Journal of Social Science, 5 (4), 75-94. 
Güldiken, N. ve Özekicioğlu, H. (2004). “Anadolu Üniversitelerinde Ailelerinden Uzakta Öğrenim Gören Öğrencilerin Barınmaya İlişkin Sorunları", Cumhuriyet Üniversitesi İktisadi ve İdari Bilimler Dergisi 5(1), 163-180.

Kara, Ö. (2009). Yükseköğrenimde Barınma Sorunu Türkiye'de Öğrenci Yurtları ve Dünyadan Örnekler. Yayınlanmamış Yüksek Lisans Tezi, Akdeniz Üniversitesi Sosyal Bilimler Enstitüsü, Antalya.

Kaya, E., Bal, D. A., Sezek, F. ve Akın, M. (2005). Sinıf Ortamı ve Barınma Sorunlarından Kaynaklanan Olumsuzlukların Öğrenci Başarısı Üzerine Etkisi. Erzincan Eğitim Fakültesi Dergisi, 7 (2), 41-51.

Koç, E. (2013). Tüketici Davranışı ve Pazarlama Stratejileri. Ankara: Seçkin Yayıncılık.

Koçbeker, D. V. (2007). Alâeddin Keykubat Yerleşkesinde Yurtlarda Barınan Öğrencilerin Sorunlarının Eğitimlerindeki Başarı Düzeylerine Etkisi. Yayınlanmamış Yüksek Lisans Tezi, Selçuk Üniversitesi Fen Bilimleri Enstitüsü, Konya.

Koçoğlu, C. (2014). İnternet Reklamlarının Tüketici Satın Alma Davranışları Üzerindeki Etkisi: Atılım Üniversitesi Örneği. Yayınlanmamış Yüksek Lisans Tezi, Atılım Üniversitesi Sosyal Bilimler Enstitüsü, Ankara.

Kotler, P. (2000). Marketing Management, New Jersey.

Ok, M. A. ve Girgin, F. M. (2015). Ankara'da İki Özel Yurt İşletmesinde SERVQUAL Yöntemi İle Hizmet Kalitesinin Ölçülmesi. Yönetim Bilimleri Dergisi, 13(25), 295-323.

Özdemir, Ş. ve Yaman, F. (2007). Hedonik Alışverişin Cinsiyete Göre Farklılaşması Üzerine Bir Araştırma, Eskişehir Osmangazi Üniversitesi İktisadi ve İdari Bilimler Fakültesi Dergisi, 2(2), 81-91.

Örücü, E., ve Tavşancı, S. (2001). Gıda Ürünlerinde Tüketicinin Satın Alma Eğilimini Etkileyen Faktörler ve Ambalajlama. Muğla Üniversitesi Sosyal Bilimler Enstitüsü Dergisi. (3).

Özgüven, İ. E. (1992). Üniversite Öğrencilerinin Sorunları ve Başetme Yolları. Hacettepe Üniversitesi Eğitim Fakültesi Dergisi, (7), 5-13.

Şahbaz, R. P. ve Şapcılar, M. C. (2014). Satın Alma Karar Sürecini Etkileyen Faktör Olarak Ailenin Seyahat Acentaları Müşterileri Açısından Analizi. İşletme Araştırmaları Dergisi, 6(4), 69-86.

Şahin, İ., Fırat, N. Ş., Zoraloğlu, Y. R. ve Açıkgöz, K. (2009). Üniversite Öğrencilerinin Sorunları. E-Journal of New World Sciences Academy, 4(4), 1435-1449.

Şeker, R., Derya, Ç. ve Abdulkadir Ö. (2004). Çevresel Faktörlerin Üniversite Öğrencilerinin Başarı Düzeyine Etkileri. XIII. Ulusal Eğitim Bilimleri Kurultayı İnönü Üniversitesi Eğitim Fakültesi, Malatya.

Tarı, R. ve Pehlivanoğlu, F. (2007). Kocaeli İlinde Tüketici Davranışlarının Gelir-Harcama Grupları İlişkisi Açısından Analizi. Kocaeli Üniversitesi Sosyal Bilimler Enstitüsü Dergisi, 1(13), 192-210.

Taşyürek, N. (2010). Reklam ve Reklamın Tüketicilerin Satın Alma Davranışları Üzerindeki Etkisi: Bir Alan Araştırması. Yayınlanmamış Yüksek Lisans Tezi, Atılım Üniversitesi Sosyal Bilimler Enstitüsü. Ankara. 
Tekin, M., Yıldız, M., Akyüz, M. ve Uğur, O. A. (2007). Karaman Yükseköğrenim Kredi ve Yurtlar Kurumunda Kalan Üniversite Öğrencilerinin Rekreatif Etkinliklere Katılım ve Beklentilerinin İncelenmesi. Erzincan Eğitim Fakültesi Dergisi, 9(1), 121-135.

Turan, A. H. ve Ünsel, A. (2014). Üniversite Öğrencilerinin Yurt Memnuniyetleri Anketi. Siyaset, Ekonomi ve Yönetim Araştırmaları Dergisi, 2(4), 91-100.

Türkay, A. (2011). Satın Alma Davranışları Açısından Üniversite Öğlenciler Arasında Marka Bağımlılı̆̆ının Önemi: Batı Akdeniz Üniversitesi Üzerinde Bir Uygulama, Yayınlanmamış Yüksek Lisans Tezi, Süleyman Demirel Üniversitesi Sosyal Bilimler Enstitüsü, Isparta.

Ural, A. ve Kılıç, İ. (2006). Bilimsel Araştırma Süreci ve SPSS İle Veri Analiz, Ankara; Detay Yayıncilik.

Ünlüönen, K. ve Tayfun, A. (2003). Turistlerin Yerli Halkın Tüketim Davranışlarına Etkileri Üzerine Ampirik Bir Araştırma. Muğla Üniversitesi Sosyal Bilimler Enstitüsü Dergisi, (10).

Yavuzer, H., Meşeci, F., Demir, İ. ve Sertelin, Ç. (2005). Günümüz Üniversite Gençliğinin Sorunları. Hasan Ali Yücel Eğitim Fakültesi Dergisi, (1), 79-91.

Yükselen, C. (2006). Pazarlama İlkeler Yönetim. Ankara: Detay Yayıncılık. 